\title{
Public Communication for Covid-19 Disaster Mitigation
}

\author{
Rosalina Kumalawati ${ }^{1}$ Karnanto Hendra Murliawan ${ }^{2}$ Astinana Yuliarti ${ }^{3 *}$ Nasruddin $^{1}$ \\ Arif Rahman Nugroho ${ }^{1}$ \\ ${ }^{1}$ Geography, Faculty of Social and Politic Science, Lambung Mangkurat University, Banjarmasin, Indonesia \\ ${ }^{2}$ The Ministry of Agrarian Affairs and Spatial Planning/National Land Agency (ATR/BPN) \\ ${ }^{3}$ Communication Science, Faculty of Social and Politic Science, Lambung Mangkurat University, Banjarmasin, \\ Indonesia \\ ${ }^{*}$ Corresponding author. Email: astinana.yuliarti@ulm.ac.id
}

\begin{abstract}
Covid-19 (Corona Viruse Desease) is a non-natural disaster that has swept the world. Countries affected by the virus include China, Japan, the United States, Singapore, Korea and dozens of other countries including Indonesia. The purpose of this study was to determine the extent of public communication carried out through the media to the public regarding the dangers of the covid-19 pandemic". The research method uses the library research method which refers to the resources available online, literature studies and analysis of text framing in the mass media about news about Covid-19 both print and online. This research presents public communication for Covid-19 disaster mitigation. Public communication here is the government's public communication in handling Covid-19. The findings of the study are that public communication can support Covid-19 disaster mitigation. The limitations of this study limit the mass media under study and limit information about Covid19. The results showed the role of public communication determines the success of the government and the region in providing information about the Covid-19 disaster that occurred. The problem that often arises is the lack of uniformity of understanding of the characteristics of the Covid-19 outbreak so that information confusion occurs. There are still many who do not know the dangers of Covid-19 so here the role of the mass media is needed. Optimization of public communication is essential for the success of Covid-19 Disaster Mitigation. Successful mitigation is expected to minimize the spread of Covid-19 and minimize fatalities. Synergy and cooperation between the central government, regional governments, mass media and the community are also very much needed in the distribution of Covid-19 information, including regarding the necessary mitigation. Successful synergy and collaboration are expected to be one of the solutions in reducing the spread of Covid-19 and fatalities.
\end{abstract}

Keywords: Public communication, mitigation, disaster, covid-19.

\section{INTRODUCTION}

Covid-19 (Corona Viruse Desease) is a non-natural disaster that has swept the world. December, 2019, a local outbreak of pneumonia with initially unknown cause was detected in Wuhan (Hubei, China), and quickly determined to be caused by a new coronavirus [10]. Countries affected by the virus include China, Japan, the United States, Singapore, Korea and dozens of other countries including Indonesia [6] Corona virus or also called Covid-19 (Corona Virus Disease 2019) was first discovered in Wuhan City, China at the end of December 2019 [18]. The symptoms of Covid-19 are flulike symptoms that are accompanied by fever, runny nose, dry cough, sore throat, and headache [24]. Covid-19 is very dangerous because the infectious virus quickly infects the respiratory system and kills [23].

The Covid-19 disaster has a very wide influence on the health and economic conditions of each [7]. The COVID19 pandemic was the first health crisis and hit the whole world [2]. The Covid-19 disaster also influenced changes in consumer behavior in daily life including buying various products to meet daily needs [3]; [22]. Many people lost their jobs, and many entrepreneurs closed their business activities [6]. There are still many people who do not fully know about the dangers of Covid-19. The limited information received by the public is one of the factors causing it. Seeing this it is very necessary for public communication.

Public communication will be successful and effective when there is clarity, accuracy of the contents of the message, the media used is easily understood and captured by the recipient [16]. Public communication is needed to support the success of Covid-19 disaster mitigation. The existence of public communication through existing mass media is expected to make it easier for the public to get information about Covid-19 and find out the symptoms and effects of Covid-19. It is easy for the community to obtain accurate information which is expected to make the community more obedient to the information and appeals from the government to prevent the spread of Covid-19. During this time there are still many people who are less 
concerned with the existing appeal from the government so that the spread of Covid-19 is increasing [9].

Mass media is one form of public communication that exists. The current condition is the role of the mass media is very large such as the early warning system and education for the community. Through the mass media, the public can easily receive information. The more the public gets information about the dangers of Covid-19, it is hoped that the public will be more careful. Based on the existing background it is necessary to conduct research on Public Communication for Covid-19 Disaster Mitigation. The purpose of this study was to determine the extent to which the process of public communication through the media was related to education in providing Surabaya-related payments from the co-19 pedemic.

\section{LITERATURE REVIEW}

Communication is also seen as the process of giving signals according to certain rules [11]. The word signal in the form of verbal and nonverbal has certain rules [12]. Communication is the science related to how to achieve effective communication in human interaction to obtain existing information [15]. Communication here is public communication for Covid-19 disaster mitigation. Public communication using existing mass media.

Communication will be successful if mutual understanding arises, between the two parties, between the sender and recipient of information can understand [15]; [19]. The recipient here is the public, while the sender is the existing mass media. The mass media in this study is the mass media that informs about Covid-19. Public communication will be successful and effective when there is clarity, accuracy of the contents of the message, the media used is easily understood and captured by the recipient [16].

Public communication at this time is needed because the spread and loss of life due to Covid-19 frequency continues to increase. The development of Covid-19 occurred in developed and developing countries. The impact of Covid19 is very big for human health and survival. The death toll from Covid-19 continues to increase every day and every time, seeing this much needed public communication. Successful public communication is expected to minimize fatalities and reduce the rate of spread of Covid-19 (see figure 1).

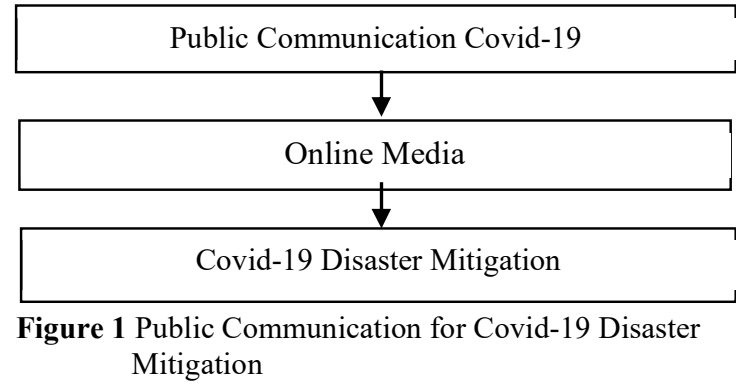

\section{METHOD}

This type of research uses qualitative and descriptive approaches. Qualitative research methods, namely understanding the phenomenon that is happening, which is being experienced by research subjects, both in attitude, behavior, motivation, actions [6]; [17]; [14]; [9]. The important thing for the development of this work is the selection of a number of websites to be examined, the sample list used is representative of the main web site that contains content on the issue of Public Communication which is conducted in connection with the mitigation of the Covid-19 pandemic disaster [20]. Data collection through documentation study by collecting news texts purposively. The author describes the Covid-19 phenomenon by analyzing every information through print, electronic and online media, related to the foundation of public communication theory.

The unit of analysis is the reporting of the discovery of the first Covid-19 patient in Indonesia. Determination of criteria in the selection of news samples based on the first time found a case of Covid-19, March 2, 2020 (see Table 1). The reason for choosing the media is based on the highest rating and the highest number of readers. In addition, the news in the online media has a good reporting standard according to journalistic rules.

The framing analysis technique used in this study is the Robert M. Entman analysis model. Framing analysis seeks to uncover public communication carried out by the government then constructed by online media. The concept of framing to describe the selection process of news framing related to the Covid-19 disaster which was constructed by the mass media [13]; [1]. This study refers to the use of the credibility element where the observations made in various studies are based on references from books and previous studies that are guaranteed credible to be used as a reference [1]. Researchers chose the framing device Robert Entman because the framing device entman was able to assist researchers in describing the framing of news related to the covid-19 pandemic conducted by online media. Framing is seen as placing information in a more specific context so that the issues discussed get a larger portion than the other issues (see Table 2).

Table 1 Research Variable

\begin{tabular}{|l|l|l|}
\hline Purpose & Variables & Data collection \\
\hline $\begin{array}{l}\text { Public Communication for Covid-19 Disaster } \\
\text { Mitigation }\end{array}$ & Okezone.com & Secondary Data \\
\cline { 2 - 3 } & Tribunnews.com & Secondary Data \\
\hline
\end{tabular}




\begin{tabular}{|l|l|l|}
\hline Purpose & Variables & Data collection \\
\hline \multirow{5}{*}{} & Detik.com & Secondary Data \\
\cline { 2 - 3 } & Sindonews.com & Secondary Data \\
\cline { 2 - 3 } & Kompas.com & Secondary Data \\
\cline { 2 - 3 } & Liputan6.com & Secondary Data \\
\cline { 2 - 3 } & Merdeka.com & Secondary Data \\
\cline { 2 - 3 } & Suara.com & Secondary Data \\
\cline { 2 - 3 } & Idntimes.com & Secondary Data \\
\cline { 2 - 3 } & Cnnindonesia.com & Secondary Data \\
\hline
\end{tabular}

Source: $[5,21]$

Table 2 Analysis of Framing

\begin{tabular}{|l|l|}
\hline Define Problems & $\begin{array}{l}\text { First element as master framing. Here, we can see how an event is } \\
\text { understood. Whether the news is positive or negative. }\end{array}$ \\
\hline Diagnose Causes & $\begin{array}{l}\text { Find and estimate the source of the problem. This dimension seeks or } \\
\text { seeks to know how the event is understood, occurs and what or who is } \\
\text { considered to be the source of the cause. }\end{array}$ \\
\hline Make moral judgement & $\begin{array}{l}\text { An assessment of the moral values used to legitimize or argue for an } \\
\text { action or idea being made }\end{array}$ \\
\hline Treatment recommendation & $\begin{array}{l}\text { What efforts or solutions are offered and done to resolve the problem. } \\
\text { This settlement depends on the issue and who caused the problem (the } \\
\text { first element) }\end{array}$ \\
\hline
\end{tabular}

Source: [13]

\section{RESULT AND DISCUSSION}

This study focuses on examining how online media is framing news about the Covid-19 outbreak disaster. The mass media under study are focused on online media, because of the condition of the community's need for actual and factual news, the presence of online media as the main alternative to answer the wishes of the people who really need information quickly, precisely and accurately. The study was conducted on news published by ten selected online media on 2 March 2020 because on the date of the test it can be assessed how responsive the government is in conducting public communication to the public through the media to answer various curiosity and curiosity of the public regarding the discovery of the first case of Covid-19 in Indonesia. The role of the media here is very important in presenting news and education how the public should behave in the face of this epidemic. The role of the media here is in the news frame about Covid-19 (see Table 3).

Table 3 Framing Analysis on Online Media

\begin{tabular}{|c|c|c|c|c|c|}
\hline No & Title News & Date & Time & Media & Explanation \\
\hline 1. & $\begin{array}{lr}\text { Menkes } & \text { Terawan } \\
\text { Sebut } & \text { Korona } \\
\text { COVID-19 } & \text { Bisa } \\
\text { Sembuh Sendiri, Ini } \\
\text { Kuncinya [31] }\end{array}$ & $\begin{array}{c}2 \\
\text { maret } \\
2020\end{array}$ & $\begin{array}{c}13.42 \\
\mathrm{pm}\end{array}$ & Okezone.com & $\begin{array}{l}\text { Minister of Health urges people not to panic } \\
\text { because the disease can be combated with a good } \\
\text { immune system by maintaining health and hygiene }\end{array}$ \\
\hline 2. & $\begin{array}{l}2 \text { orang yang tinggal } \\
\text { bersama WNI positif } \\
\text { Corona Dipastikan } \\
\text { Negatif, Kemenkes } \\
\text { jelaskan } \\
\text { penyebabnya [34] }\end{array}$ & $\begin{array}{c}2 \\
\text { maret } \\
2020\end{array}$ & $\begin{array}{c}22.24 \\
\mathrm{pm}\end{array}$ & Tribunnews.com & $\begin{array}{l}\text { After examining the Household assistant the } \\
\text { results were negative. Keep in mind the symptoms } \\
\text { that may be an indication of the corona virus, if it } \\
\text { is not already done then it must be anticipated so } \\
\text { as not to contract the virus }\end{array}$ \\
\hline 3. & $\begin{array}{l}\text { Menkes: Tak Perlu } \\
\text { Fobia, Gerakan } \\
\text { Hidup Sehat Cukup } \\
\text { Cegah Corona }[26]\end{array}$ & $\begin{array}{c}2 \\
\text { maret } \\
2020\end{array}$ & $\begin{array}{c}23.17 \\
\mathrm{pm}\end{array}$ & Detik.com & $\begin{array}{l}\text { Terawan said the healthy living movement could } \\
\text { prevent the transmission of the corona virus, he } \\
\text { hoped the healthy lifestyle would continue to be } \\
\text { carried out by the community }\end{array}$ \\
\hline 4. & $\begin{array}{l}2 \text { Warga Terinfeksi } \\
\text { Corona, Pintu Masuk }\end{array}$ & $\begin{array}{c}2 \\
\text { maret } \\
2020 \\
\end{array}$ & $\begin{array}{c}14.52 \\
\mathrm{pm}\end{array}$ & Sindonews.com & $\begin{array}{l}\text { PDIP politicians say that Indonesia has a very large } \\
\text { number of islands that serve as entrances from } \\
\text { various countries, border areas need to be guarded }\end{array}$ \\
\hline
\end{tabular}




\begin{tabular}{|c|c|c|c|c|c|}
\hline No & Title News & Date & Time & Media & $\begin{array}{l}\text { Explanation } \\
\end{array}$ \\
\hline & $\begin{array}{l}\text { Perbatasan Perlu } \\
\text { Diperketat [32] }\end{array}$ & & & & $\begin{array}{l}\text { because they are very vulnerable to the entry and } \\
\text { exit of citizens. }\end{array}$ \\
\hline 5. & $\begin{array}{lr}\text { Soal Virus } & \text { Corona, } \\
\text { Politisi } & \text { PSI: } \\
\text { Penanganan } & \text { dan } \\
\text { Sosialisasi } & \text { Harus } \\
\text { Masif } & {[28]}\end{array}$ & $\begin{array}{c}2 \\
\text { maret } \\
2020\end{array}$ & $\begin{array}{c}23.36 \\
\mathrm{pm}\end{array}$ & Kompas.com & $\begin{array}{l}\text { Member of Commission IV Sulut Melky said that } \\
\text { the Health Department must be massive in } \\
\text { socializing to the citizens related to corona virus } \\
\text { prevention and its handling policies. And the } \\
\text { community is also expected to not be too panicked } \\
\text { in the face of this outbreak, but must remain } \\
\text { vigilant with maintaining personal health and } \\
\text { hygiene and following virus prevention tips of } \\
\text { corona }\end{array}$ \\
\hline 6. & $\begin{array}{l}5 \text { Ciri-ciri Terinfeksi } \\
\text { Virus Corona, Serta } \\
\text { Cara Pencegahan } \\
\text { Agar Tidak Tertular } \\
{[29]}\end{array}$ & $\begin{array}{c}2 \\
\text { maret } \\
2020\end{array}$ & $\begin{array}{c}21.49 \\
\mathrm{pm}\end{array}$ & Liputan6.com & $\begin{array}{l}\text { Fever, headaches, flu / colds, severe cough and } \\
\text { sore throat and shortness of breath are some of the } \\
\text { characteristics of a person affected by covid-19. To } \\
\text { prevent people affected are diligent hand washing, } \\
\text { meet your nutritional needs, avoid direct contact } \\
\text { with people who have a fever and cough, use a } \\
\text { mask when having activities outside the home, } \\
\text { smart to choose a trip, and follow the advice given } \\
\text { by health care providers. }\end{array}$ \\
\hline 7. & $\begin{array}{lr}\text { Perhatikan } & \text { Ciri-ciri } \\
\text { Terinfeksi } & \text { Virus } \\
\text { Corona, Jaga } & \text { Etika } \\
\text { Batuk [30] } & \end{array}$ & $\begin{array}{c}2 \\
\text { maret } \\
2020\end{array}$ & $\begin{array}{c}18.41 \\
\mathrm{pm}\end{array}$ & Merdeka.com & $\begin{array}{l}\text { The rapid spread of the corona virus epidemic } \\
\text { requires careful handling, especially since } \\
\text { Indonesia is a country that has a densely populated } \\
\text { population. There are still many health agencies in } \\
\text { areas that are not big cities that cannot handle } \\
\text { corona virus infection patients. Therefore it is very } \\
\text { important to minimize and prevent the spread of } \\
\text { this virus wherever we are }\end{array}$ \\
\hline 8. & 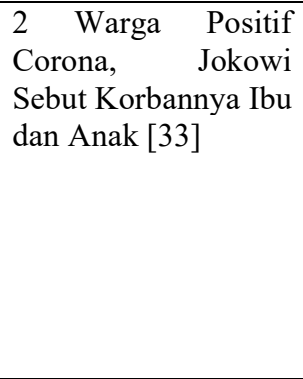 & $\begin{array}{c}2 \\
\text { maret } \\
2020\end{array}$ & $\begin{array}{l}11.43 \\
\text { pm. }\end{array}$ & Suara.com & $\begin{array}{l}\text { President Jokowi in his speech said that there } \\
\text { was information last week that there were } \\
\text { Japanese people who went to Indonesia later } \\
\text { and were checked there, apparently the } \\
\text { Indonesian team's corona was directly } \\
\text { searching. Who is this Japanese to visit to } \\
\text { Indonesia. Searched and found. It has been } \\
\text { found that people who have been affected by } \\
\text { the corona virus are associated with two } \\
\text { people (mother and child) }\end{array}$ \\
\hline 9. & $\begin{array}{l}\text { [BREAKING] } \\
\text { Indonesia Positif } \\
\text { Kasus Virus Corona, } \\
\text { Warga Depok } \\
\text { Cemas! [27] }\end{array}$ & $\begin{array}{c}2 \\
\text { maret } \\
2020\end{array}$ & & Idntimes.com & $\begin{array}{l}\text { Minister of Health Terawan Agus Purtanto said } \\
\text { that two Indonesian citizens who were positively } \\
\text { affected by the corona virus or covid-19 who were } \\
\text { domiciled in Depok, had carried out house } \\
\text { isolation. Terawan explained the case after a } \\
\text { Japanese foreign national living in Malaysia } \\
\text { visited Indonesia }\end{array}$ \\
\hline 10. & $\begin{array}{l}\text { Kemenkes: } \\
\text { Pembantu di Rumah } \\
\text { Pasien } \quad \text { Depok } \\
\text { Negatif Corona }[25]\end{array}$ & $\begin{array}{c}2 \\
\text { maret } \\
2020\end{array}$ & $\begin{array}{l}22.30 \\
\text { pm. }\end{array}$ & $\begin{array}{c}\text { Cnnindonesia.co } \\
\mathrm{m}\end{array}$ & $\begin{array}{l}\text { The two people living in the same house with } \\
\text { patients who tested positive for co-19 had } \\
\text { examined both of them and the results were that } \\
\text { they were negative or did not have the virus. } \\
\text { Secretary of the Directorate General of Disease } \\
\text { Prevention and Control of the Ministry of Health } \\
\text { (Kemenkes) Achmad Yurianto said he would } \\
\text { continue to monitor the residence of the two } \\
\text { positive corona patients. However, it will not clean }\end{array}$ \\
\hline
\end{tabular}




\begin{tabular}{|c|l|l|l|l|l|}
\hline No & Title News & Date & Time & Media & \multicolumn{1}{c|}{ Explanation } \\
\hline & & & & & $\begin{array}{l}\text { the environment where the two patients live in } \\
\text { Depok, West Java, using disinfectants. }\end{array}$ \\
\hline
\end{tabular}

Based on the results of framing on the news published in the media Okezone.com entitled "Menkes Terawan Sebut Korona COVID-19 Bisa Sembuh Sendiri, Ini Kuncinya". It shows that the news presented by this media focuses on the role of the government in "calming" the people so that they are not too panicked in dealing with the Covid-19 issue. The government was interviewed at that time, represented by Minister of Health, Terawan Agus Purtanto that basically this virus can be resisted as long as the community maintains good immunity, health and hygiene. The same thing is similar to the approach of framing carried out by detik.com media, in the news glimpsed by the media entitled "Menkes: Tak Perlu Fobia, Gerakan Hidup Sehat Cukup Cegah Corona", in its coverage highlighting more and focusing to educate the public on how to maintain health amid the co-19 pandemic. This was carried out by the Ministry of Health Terawan who said that the healthy life movement carried out by the community could prevent transmission of the corona virus, he also hoped that the community would maintain a healthy lifestyle.

The approach taken between online media Okezone.com and detik.com based on the framing model adopted by Entman, namely Treatment recommendation in frame of news emphasizing more on recommendations, suggestions or solutions that can be done by the community amidst the ongoing pandemic in Indonesia since the first case was discovered. Emphasis is placed on news, it is hoped that the community will further increase awareness in trying to protect themselves from being exposed to viruses.

Liputan6.com framing analysis entitled "5 Ciri-ciri Terinfeksi Virus Corona, Serta Cara Pencegahan Agar Tidak Tertular" and news articles published online online merdeka.com " Perhatikan Ciri-ciri Terinfeksi Virus Corona, Jaga Etika Batuk " using a framing approach almost the same thing that emphasizes the Diagnosis Causes, which focuses on explaining to the reader what kind of attitude and addressing themselves in the spread of this virus. Liputan6.com focuses on educating its readers with very clear reviews relating to what the characteristics of someone who has been infected with Covid-19 and how to take precautions early so as not to become infected. The same thing is done by merdeka.com in framing and focusing on diagnosing Causes which focus on explaining to the reader how the characteristics of people are infected with the virus, and an appeal to focus on minimizing and preventing the spread of this virus.

Articles related to Covid-19 news published in Sindonews.com Online media have a pattern similar to the approach used in Kompas.com online media. The headline "2 Warga Terinfeksi Corona, Pintu Masuk Perbatasan Perlu Diperketat" emphasizes the aspect of Make moral judgment in which the framing of the news does not focus on describing what the corona or covid-19 virus is but focuses on packaging the news from the perspective of how authorities should be in take action to prevent the increasingly massive spread of the virus, as quoted by PDIP politicians during an interview which said that Indonesia has a lot of islands that serve as entrances from various countries, border areas need to be guarded because they are very vulnerable to the entry and exit of citizens. The same thing was also found in a news article published in Kompas.com online media with the title "Corona Virus Problem, PSI Politicians: Handling and Dissemination Must Be Massive" which in one part of the news was quoted from a member of Commission IV of North Sulawesi DPRD which says;

"The Health Office must be massive in disseminating information to citizens regarding corona virus prevention and its handling policies. And the public is also expected to not be too panicked in the face of this outbreak, but must remain vigilant with maintaining personal health and hygiene and following corona virus prevention tips ".

The piece of news article that we can see can be seen that there are different emphases made by the online media Kompas.com, which in framing the statement takes a different perspective on the moral and social approach. The community must remain calm and do not panic and the government must conduct more intensive socialization. The choice of perspective is certainly different from other media. When other media focused on the news relating to the discovery of the first covid- 19 case in Indonesia, the online media sindo.new.com and kompas.com came with a different approach that of course the information presented was something that the public really needed.

The author groups online media Tribunnews.com, Idntimes.com, cnnindonesia.co.id and Suara.com in the same discussion because the four online media have almost the same characteristics in presenting news related to the co-19 pandemic outbreak. In the release of an article on Tribunnews.com entitled "2 orang yang tinggal bersama WNI positif Corona Dipastikan Negatif, Kemenkes jelaskan penyebabnya " and also in the online media Idntimes.com entitled "[BREAKING] Indonesia Positif Kasus Virus Corona, Warga Depok Cemas!" have the same point of view in writing news. This was also found in the article "Ministry of Health: Helper at Corona Negative Depok Patient Home" in online media cnnindonesia.co.id and article "Kemenkes: Pembantu di Rumah Pasien Depok Negatif Corona " in online media Suara.com.

The articles in the four online media that have been mentioned together raise friends related to information that corona positive patients have been discovered in 
Indonesia for the first time in Indonesia. The four articles are in accordance with Robert Entman's "Define Problems" framing study, which in the framing of the news focuses on explanations related to events that occur as they are whether positive or negative.

\section{CONCLUSION}

a. The online media which are the object of research have provided balanced information regarding the Covid-19 pandemic news.

b. The emphasis of framing on each media has similarities and also differences according to the point of view of the media.

c. Media information in the News is needed by the community to help the community related to the development of the spread of the Coid-19 virus, ways of prevention and prevention.

d. The government has made public communication in the context of Covid-19 disaster mitigation to the public.

\section{REFERENCES}

[1] A. Donna, Optimalisasi Komunikasi Bencana di Media Massa sebagai Pendukung Manajemen Bencana. Jurnal Komunikasi, 01 (2016) 1-11

[2] A Purwanto, R Pramono, M Asbari, C. C. Hyun, L. M. Wijayanti, \& R. S. Putri, Studi Eksploratif Dampak Pandemi COVID-19 Terhadap Proses Pembelajaran Online di Sekolah Dasar. EduPsyCouns: Journal of Education, Psychology and Counseling, 2(1), (2020), 1-12.

[3] B. A. Pramudita, "Deretan Perubahan Perilaku Konsumen karena Corona", (2020)., https://www.

wartaekonomi.co.id/read281999/deretanperubahan-perilaku-konsumen-karena-corona diakses 30 April 2020

[4] B. Ramadhan, "Perubahan Perilaku Belanja Konsumen Indonesia Saat Covid-19”, (2020). https://teknoia.com/perilaku-konsumenindonesia-saat-covid-19-ee51b041464e diakses 30 April 2020.

[5] B. Walgito, Introduction to General Psychology. Yogyakarta: PT Andi, (2003).

[6] D. J. Aram, \& Y. Mediantara, Covid-19 dan Perubahan Komunikasi Sosial. PERSEPSI: Communication Journal, 3(1) (2010), 94-102.

[7] D. K. Yusup, M. Badriyah, D. Suyandi, \& V. S. Asih, Pengaruh bencana Covid-19, pembatasan sosial, dan sistem pemasaran online terhadap perubahan perilaku konsumen dalam membeli produk retail. http://digilib. uinsgd. ac. id, $1(1$ (2020).), 1-10.

[8] D. Mulyana, Metodologi Penelitian Kualitatif. Paradigma Baru Ilmu Komunikasi dan Ilmu Sosial Lainnya edisi revisi. PT Remaja Rosdakarya.Bandung, 2018
[9] D. R. Buana, Analisis Perilaku Masyarakat Indonesia dalam Menghadapi Pandemi Virus Corona (Covid-19) dan Kita Menjaga Kesejahteraan Jiwa. Jurnal Sosial dan Budaya Syar-i. FSH UIN Syarif Hidayatullah Jakarta. Vol. 7 No. 3 (2020), pp.217-226, DOI: $10.15408 /$ sjsbs.v7i3.15082

[10] E Dong, H Du, L Gardner, An interactive webbased dashboard to track COVID-19 in real time. The Lancet infectious diseases, 20(5) (2020), 533-534.

[11] E. Khairani, Psikologi komunikasi humas aceh dalam menyikapi pandemi corona (Pemberitaan Terkait Penyediaan Kuburan Masal oleh Juru Bicara Covid 19 Aceh). Jurnal Peurawi: Media Kajian Komunikasi Islam, 3(1) (2020), 103-119.

[12] E. S Lawasi, \& B. Triatmanto, Pengaruh Komunikasi, Motivasi Dan Kerjasama Tim Terhadap Peningkatan Kinerja Karyawan. Jurnal Manajemen dan Kewirausahaan, 5(1), (2017), 47-57.

[13] Eriyanto, Analisis Framing (Konstruksi, Ideologi dan politik Media. Yogyakarta, LKIS, 2011

[14] H. Haris, Metodologi Penelitian Kua litatif Untuk Ilmu-ilmu Sosial. Salemba Humanika. Jakarta, 2010

[15] J. Rakhmat, Psikologi komunikasi, Bandung: Remaja Rosdakarya. 2010

[16] K. D. Moore, Effective Instructional Strategies, From Theory to Practice, London: Sage Publications, 2014

[17] M. Yusuf, Metode Penelitian Kuantitatif, Kualitatif dan Penelitian Gabungan. Jakarta: Kencana, 2014

[18] N.R. Yunus, \& A.Rezki, "Kebijakan Pemberlakuan Lock Down Sebagai Antisipasi, (2020).

[19] N. W. Syam, Psikologi Sebagai Akar Ilmu Komunikasi, Bandung: Simbiosa Rekatama Media, 2011, Hal. 35.

[20] S.S.M. Hamdani, Techniques of Online Propaganda: A Case Study of Western Sahara Conflict. Online Journal of Communication and Media Technologies, 8(3) (2018), 237-243.

[21] Sugihartono, et al, Educational Psychology. Yogyakarta: UNY Press. . (2007).

[22] W. T. Rahmawati, "Ini perubahan perilaku konsumen Indonesia saat pandemi corona", (2020). https://nasional.kontan.co.id/news/iniperubahan-perilaku-konsumen-indonesia-saatpandemi-corona diakses 30 APril 2020.

[23] World Health Organization (WHO), "Novel Corona Virus Qualiti Assurance for Public Helalth", (2020).

[24] Yuliana, "Corona Virus Diseases (Covid-19): Sebuah Tinjauan Literature", Welness and Healthy Magazines, 2(1) (2020), 187-192. 
[25] CNNINDONESIA.COM (2020, 2 MARET). KEMENKES: PEMBANTU Di RUMAH PASIEN DEPOK NEGATIF CORONA. ACCESSED 6 JUNE 2020. HTTPS://WWW.CNNINDONESIA.COM/NASIONAL/20 200302222236-20-479924/KEMENKESPEMBANTU-DI-RUMAH-PASIEN-DEPOK-NEGATIFCORONA

[26] Detik.com (2020, 2 Maret). Menkes: Tak Perlu Fobia, Gerakan Hidup Sehat Cukup Cegah Corona. Accessed 6 June 2020 .https://news.detik.com/berita/d4922692/menkes-tak-perlu-fobia-gerakan-hidupsehat-cukup-cegah-corona

[27] Idntimes.com (2020, 2 Maret). [BREAKING] Indonesia Positif Kasus Virus Corona, Warga Depok Cemas. Accessed 6 June 2020. https://www.idntimes.com/news/indonesia/dinisuciatiningrum/breaking-indonesia-positif-kasusvirus-corona-warga-depok-cemas

[28] Kompas.com (2020, 2 Maret). Soal Virus Corona, Politisi PSI: Penanganan dan Sosialisasi Harus Masif. Accessed 6 June 2020 https://regional.kompas.com/read/2020/03/02/23 362641/soal-virus-corona-politisi-psipenanganan-dan-sosialisasi-harus-masif

[29] LipUtAN6.COM (2020, 2 MARET). 5 CIRI-CIRI TERINFEKSI VIRUS CORONA, SERTA CARA PENCEgAHAN AgAR TIDAK TERTUlar. $\begin{array}{lll}\text { ACCESSED } & 6 & \text { JUNE } \\ \end{array}$ HTTPS://HOT.LIPUTAN6.COM/READ/4192317/5CIRI-CIRI-TERINFEKSI-VIRUS-CORONA-SERTACARA-PENCEGAHAN-AGAR-TIDAK-TERTULAR
[30] Merdeka.com (2020, 2 Maret). Perhatikan Ciriciri Terinfeksi Virus Corona, Jaga Etika Batuk. $\begin{array}{lll}\text { Accessed } & 6 & \text { June }\end{array}$ https://www.merdeka.com/jabar/perhatikan-ciriciri-terinfeksi-virus-corona-jaga-etika-batuk.html

[31] Okezone.com (2020, 2 Maret). Menkes Terawan Sebut Korona Covid-19 bisa semubuh sindiri ini kuncinya. Accessed 6 June 2020. https://lifestyle.okezone.com/read/2020/03/02/48 1/2176824/menkes-terawan-sebut-korona-covid19-bisa-sembuh-sendiri-ini-kuncinya

[32] Sindonews.com (2020, 2 Maret). 2 Warga Terinfeksi Corona, Pintu Masuk Perbatasan Perlu Diperketat. Accessed 6 June 2020. https://nasional.sindonews.com/berita/1 543141/15/2-warga-terinfeksi-coronapintu-masuk-perbatasan-perludiperketat

[33] SuARA.COM (2020, 2 MARET). 2 WARga PositiF CORONA, JoKOWI SEBUT KorbanNYA IBU DAN ANAK. ACCESSED 6 JUNE 2020 HTTPS://WWW.SUARA.COM/NEWS/2020/03/02/114 305/2-WARGA-POSITIF-CORONA-JOKOWI-SEBUTKORBANNYA-IBU-DAN-ANAK

[34] Tribunnews.com (2020, 2 Maret). 2 orang yang tinggal bersama WNI positif Corona Dipastikan Negatif, Kemenkes jelaskan penyebabnya. Accessed 6 June 2020 .https://www.tribunnews.com $/$ regional $/ 202$ 0/03/03/2-orang-yang-tinggal-dengan-2-wnipositif-corona-dipastikan-negatif-kemenkesjelaskan-penyebabnya 